\title{
Determination of Ecological and Carbon Footprints of Adıyaman Directorate of Provincial Agriculture and Forestry Staffs
}

\author{
Mehmet Firat Baran $^{1 *}$, Osman Gökdoğan ${ }^{2}$, Ömer Eren ${ }^{3}$, Yılmaz Bayhan ${ }^{4}$ \\ ${ }^{1}$ Department of Biosystems Engineering, University of Siirt, Turkey(ORCID: 0000-0002-7657-1227) \\ 2 Department of Biosystems Engineering, University of Nevşehir Hacı Bektaş Veli, Turkey(ORCID: 0000-0002-4933-7144) \\ ${ }^{3}$ Department of Biosystems Engineering, University of Hatay Mustafa Kemal, Turkey(ORCID: 0000-0001-6283-4367) \\ ${ }^{4}$ Department of Biosystems Engineering, University of Tekirdağ Namık Kemal, Turkey(ORCID: 0000-0003-1099-3571)
}

(Ilk Geliş Tarihi 16 Ocak 2019 ve Kabul Tarihi 4 Mart 2019)

(DOI: $10.31590 /$ ejosat.)

REFERENCE: Baran M.F, Gökdoğan, O., Eren,Ö. \& Bayhan,Y. (2019). Determination of Ecological and Carbon Footprints of Adiyaman Directorate of Provincial Agriculture and Forestry Staffs, Avrupa Bilim ve Teknoloji Dergisi, (15), 280-288

\begin{abstract}
Humans have always benefited from natural sources to satisfy their needs. Today, with the increase in population, the natural resources on our earth are decreasing and assumed to be consumed in the near future because of the consciousness of the individuals and the consciousness of consumption away from sustainability. It is important to determine how many planets the world will need in the future if the individual continues to live that way with his current consumption habits. The concept of ecological footprint emerges in determining this need. In this study, ecological and carbon footprints were calculated and evaluated according to the consciousness and consumption habits of Adiyaman Directorate of Provincial Agriculture and Forestry staffs. Web-based "Ecological Footprint Calculation Survey" was used as data collection tool in the research. Descriptive statistics such as mean, standard deviation were used in the analysis of the data. As a result of the calculations, the average ecological footprint of technical and administrative staffs was determined as 2.37 gha person ${ }^{-1}$, the average carbon footprint was 14.52 tons person ${ }^{-1}$ and the biocapacity deficit caused by technical and administrative staffs was -0.93 gha person ${ }^{-1}$. According to these results, at least 1.41 worlds are needed for Adiyaman Directorate of Provincial Agriculture and Forestry staffs for a sustainable life.
\end{abstract}

Keywords: Adiyaman, biocapacity deficit, carbon footprint, ecological footprint, sustainability

\section{Adıyaman İl Tarım ve Orman Müdürlüğü Çalışanlarının Ekolojik ve Karbon Ayak İzinin Belirlenmesi}

\begin{abstract}
Öz
İnsanoğu ihtiyaçlarını karşılamada daima doğal kaynaklardan faydalanmıştır. Bugün nüfusun artmasıyla birlikte, bireylerin bilinçsizce ve sürdürülebilirlikten uzak tüketim anlayışı nedeniyle dünyamız üzerindeki doğal kaynaklar azalamakta ve yakın bir gelecekte tükeneceği varsayılmaktadır. Bireyin mevcut tüketim alışkanlıkları ile yaşamına bu şekilde devam etmesi halinde, gelecekte dünya gibi kaç gezegene ihtiyaç duyacağının belirlenmesi önemlidir. Bu ihtiyacı belirlemede karşımıza ekolojik ayak izi kavramı çıkmaktadır. Bu çalışmada, Adıyaman İl Tarım ve Orman Müdürlüğü çalışanlarının bilinç ve tüketim alışkanlıklarına bağlı olarak ekolojik ayak izleri hesaplanmış ve değerlendirilmiştir. Araştırmada veri toplama aracı olarak web-tabanlı "Ekolojik Ayak İzi Hesaplama Anketi" kullanılmıştır. Verilerin analizinde; ortalama, standart sapma gibi betimsel istatistikler kullanılmıştır. Hesaplamalar sonucunda, teknik ve idari personellerin ekolojik ayak izi ortalaması 2.37 kha kişi ${ }^{-1}$, karbon ayak izi ortalaması 14.52 ton kişi ${ }^{-1}$ ve sebep oldukları

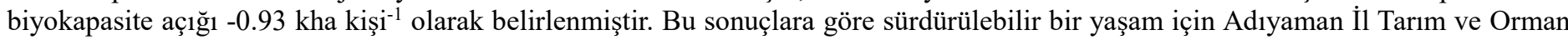
Müdürlüğü çalışanlarına yaklaşık olarak 1.41 dünya gerekmektedir.
\end{abstract}

Anahtar kelimeler: Adıyaman, biyokapasite açığı, ekolojik ayak izi, karbon ayak izi, sürdürebilirlik 


\section{Introduction}

People have always benefited from natural resources as much as the day-to-day to meet their needs. Along with population growth, the natural resources on the earth are also decreasing. How many planets like the world are needed in the future if they continue to live in the context of existing consumption habits? The determination of the answer to this question is important for a habitable world to be left to future generations. The "ecological footprint" in this context is one of the methods used.

Ecological footprint is the biologically fertile soil and water area needed to produce the resources consumed by an individual, community, or activity through current technology and resource management, and to dispose of the resulting waste. It is expressed in "global hectare (gha)". This includes the infrastructure and necessary areas for plant cover to absorb waste carbon dioxide (Lin et al., 2016).

The ecological footprint is one of the most effective means of giving an idea of the impact of a person on nature. Everyone has an influence on the earth because people consume the products and services of nature. The first study on ecological footprint was made by William E. Rees in 1992. The concept and related calculation methods were first performed by Dr. Mathis Wackernagel in his doctoral dissertation. The measure obtained in the study was also called Ecological Footprint. Wackernagel and Rees, in their book published in 1995, detailed the concept of ecological footprint and the relationship between sustainable development and the methods of calculation. Ecological footprint in this direction; to give clues for sustainable life and as an important indicator at the point of putting the burden that human beings have on this planet (Akyüz et al., 2016).

According to WWF's global footprint network, the global ecological footprint of the world and Turkey in 2014 was 20.602 and 0.249 billion gha respectively. The ecological footprint per capita was calculated as 2.84 gha and 3.21 gha, respectively (Figure 1).

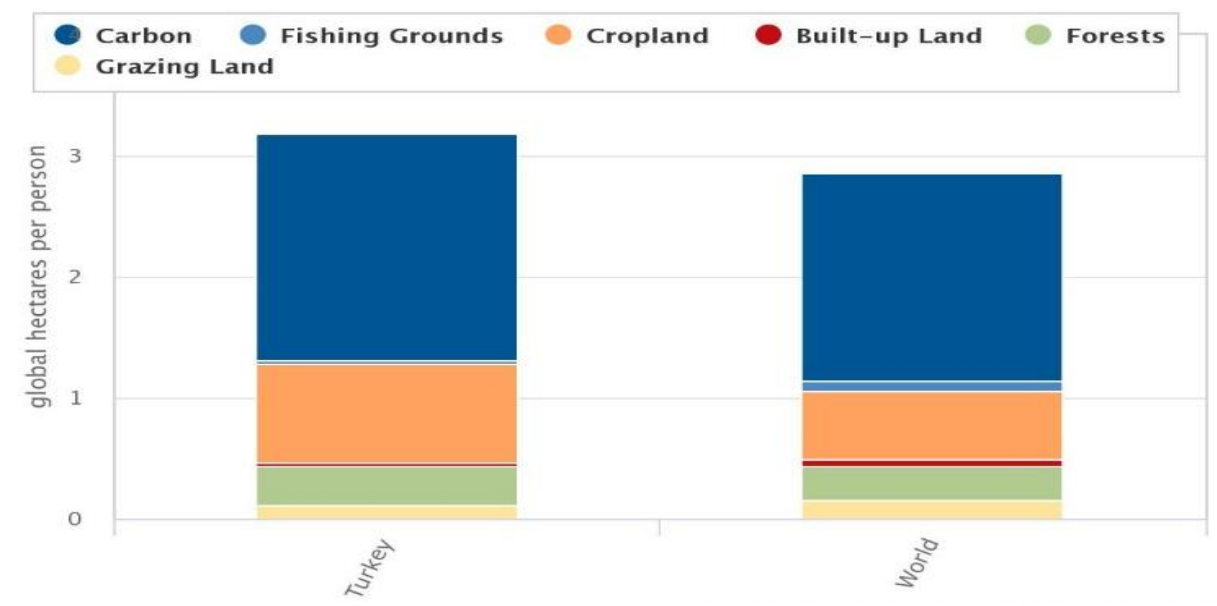

Figure 1. Ecological footprint per person for Turkey and World (GFN, 2019)

The capacity of ecosystems to regenerate what people demand from those surfaces. Life, including human life, competes for space. The biocapacity of a particular surface represents its ability to renew what people demand. Biocapacity is therefore the ecosystems' capacity to produce biological materials used by people and to absorb waste material generated by humans, under current management schemes and extraction technologies. Biocapacity can change from year to year due to climate, management, and also what portions are considered useful inputs to the human economy. In the National Footprint Accounts, the biocapacity of an area is calculated by multiplying the actual physical area by the yield factor and the appropriate equivalence factor. Biocapacity is usually expressed in global hectares (gha) (Lin et al., 2016).

Each year, the Global Footprint Network (GFN) measures the biological capacity of more than 150 countries worldwide and publishes the National Footprint Accounts (NFA). The biocapacity per capita of the world and Turkey in 2014 was calculated as 1.68 gha and 1.44 gha, respectively (Figure 2). 


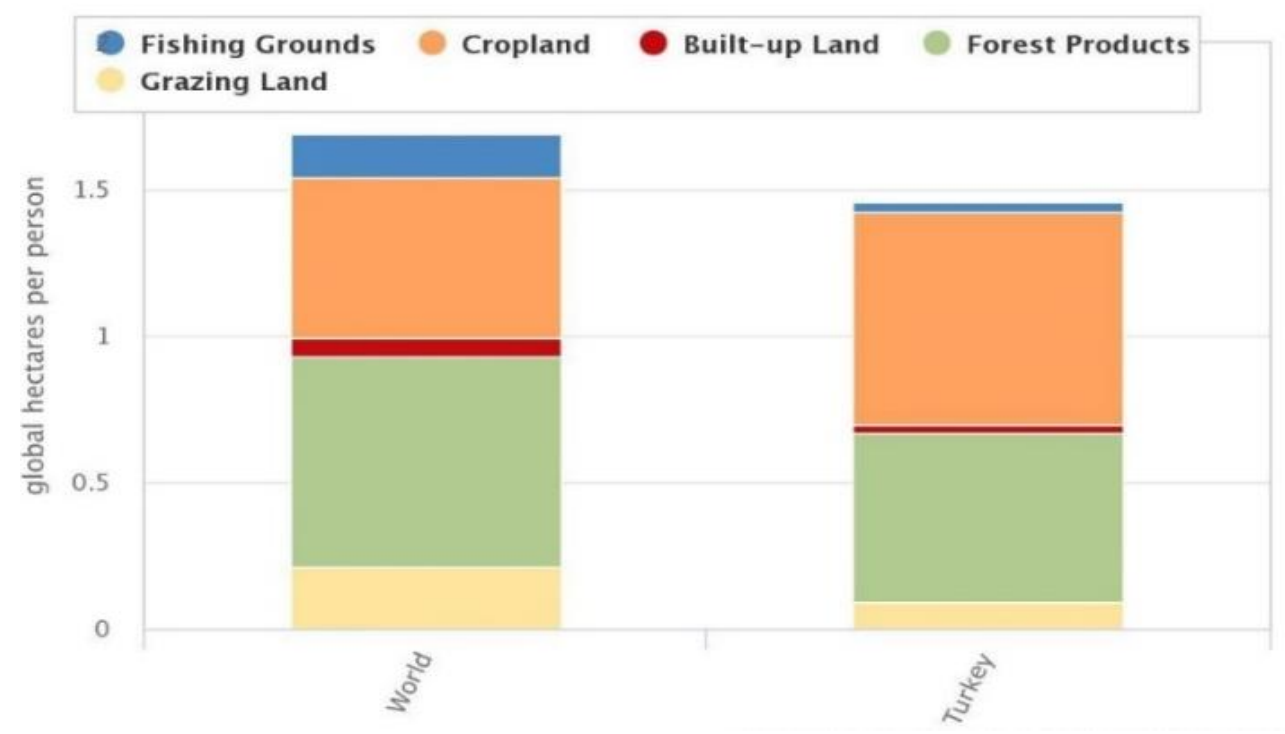

Figure 2. Biocapacity per person for World and Turkey (GFN, 2019)

There are many studies in the international literature using ecological footprint calculation methods that show that ecological footprints are an effective tool for individuals to perceive the effects of consumption habits on nature (Schaller, 1999; Dawe et al, 2004; Ryu and Brody, 2006; Janis, 2007; Wada et al., 2007; Niccolucci et al., 2012).

When the national literature studies are examined, the global importance of the ecological footprint in Turkey is explained and emphasized (Dinç, 2015). Ecological footprints have been proposed as a means of environmental education without changing the awareness, attitudes and behaviors of primary school students, prospective teachers and engineering students towards sustainable life (Keleş, 2007; Keleş et al., 2008; Erdoğan and Tuncer, 2009; Keleş, 2011; Coşkun, 2013; Çetin, 2015; Eren et al., 2016). There are researches that include ecological footprint calculations depending on consciousness and consumption habits of the university staff (Ak1llı et al., 2008; Akyüz et al., 2016; Eren et al., 2017; Eren et al., 2018).

As a result of literature surveys, ecological footprint studies conducted for Turkey were found to be very low. For this purpose, ecological and carbon footprints were calculated and evaluated according to the consumption habits of Adiyaman Directorate of Provincial Agriculture and Forestry staffs.

\section{Material and Method}

\subsection{Material}

The main material of the study is the data obtained with the questionnaire applied to the instructors who are currently working at Adiyaman Directorate of Provincial Agriculture and Forestry. In addition to this, related articles, theses, reports and notifications were also used.

\subsection{Method Used to Collect Data}

Staff working in Adıyaman Directorate of Provincial Agriculture and Forestry were accepted as the target group. The data were collected on May 2018 through a questionnaire interviewed with the target audience. The first part of the questionnaire was prepared to determine the demographic characteristics of the participants. In the second part of the questionnaire, questions were asked about food, travel, home and other life habits to determine ecological footprints. In the preparation of these questionnaire questions, the ecological footprint calculation engine "Ecological Footprint Calculation Survey" was used.

As the main group, 145 staff working at Adıyaman Directorate of Provincial Agriculture and Forestry were taken into consideration. However, because of the fact that two staff are leaved, no questionnaire could be done with them. A total of 143 staffs were interviewed.

\subsection{Method of Analysis of Data}

In order to calculate the ecological footprint of the teaching staff, ecological footprint calculation engine developed by the World Wildlife Fund (WWF) was used (Figure 3). 


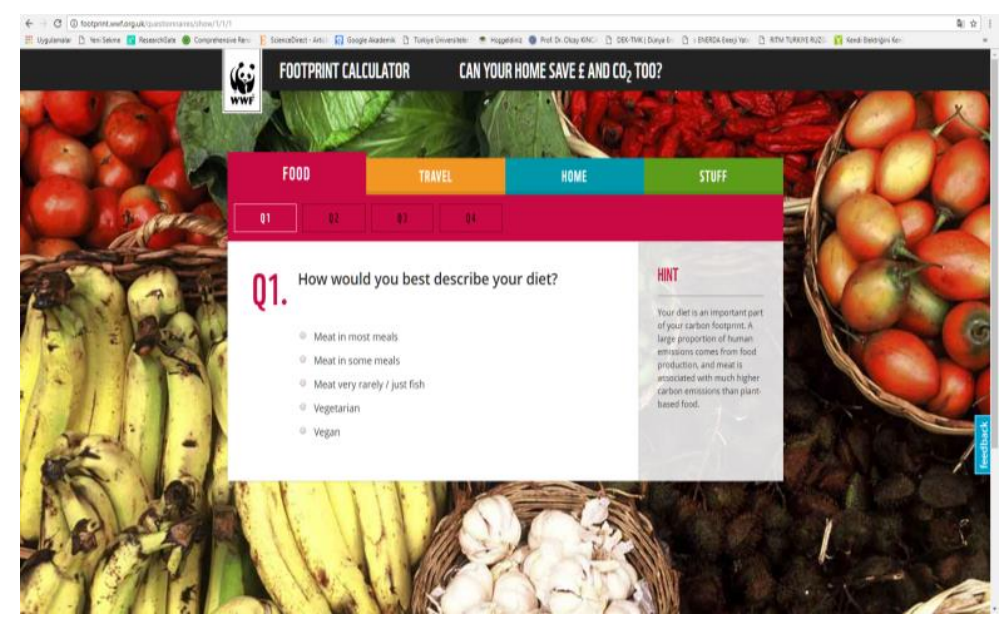

Figure 3. Ecological footprint calculation engine (WWF, 2018)

The data obtained as a result of the surveys are processed for the calculation engine and the ecological and carbon footprints of the staffs of Adiyaman Directorate of Provincial Agriculture and Forestry are calculated. The obtained findings are summarized by the frequency table. The Kolmogorov-Smirnov test was used to investigate whether the ecological and carbon footprint data were normally distributed. It has been determined that they do not show normal distribution. For this reason, the significance between the variables was questioned by the Kruskal-Wallis test.

Biocapacity (BC) reserve (+) or deficit (-) calculated by the following equations (Lin et al., 2016):

$B C($ reserve or deficit $)=B C-E F$

Here $\mathrm{BC}$ was biocapacity per person. Biocapacity per person is the productive area that exists per resident in that country. It is their «ecological income». This value is 1.44 gha person $^{-1}$ for Turkey according 2014 data (GFN, 2019). EF was calculated ecological footprint per person of consumption. Biocapacity deficit is always negative values.

Number of Earths calculated by the following equations (GFN, 2019):

Number of Earths $=\frac{E F}{B C \text { for World }}$

Biocapacity per person value for World is 1.68 gha person $^{-1}$ according 2014 data (GFN, 2019).

\section{Results and Discussion}

\subsection{Demographic Characteristics}

The average age of the participants in the survey is approximately 43 and the number of individuals in the family is approximately 4 persons. In addition, the duration of the staff is approximately 14 years (Figure 4 ). $22.38 \%$ of the staff members were female and $77.62 \%$ were male.

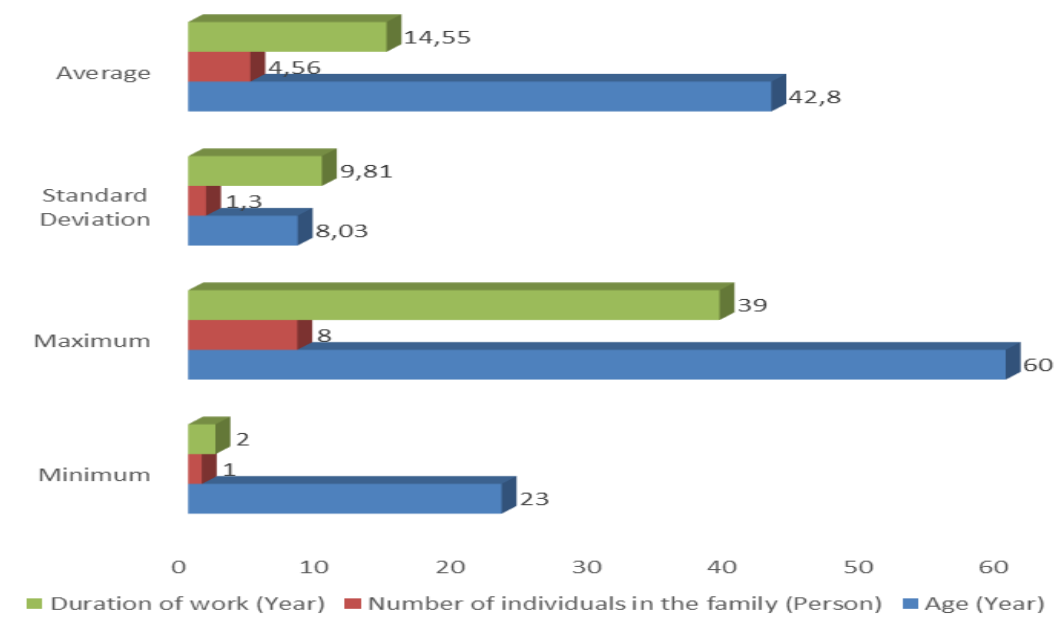


Figure 4. Demographic characteristics of participants

In addition, $41.26 \%$ of the staff were engineer, $16.08 \%$ were technician, $16.08 \%$ were veterinary, $13.99 \%$ were officer/employee, $6.99 \%$ were director, $4.90 \%$ were operator and $0.70 \%$ were sociologist (Figure 5).

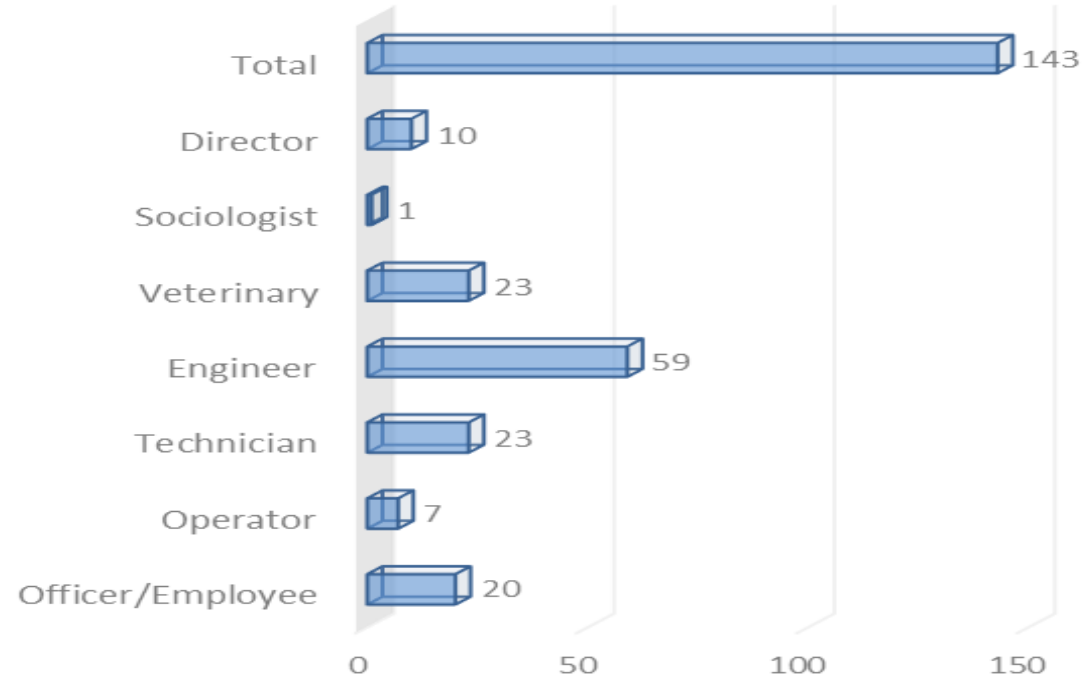

Figure 5. Titles of participants

\subsection{Assessments}

\section{Ecological Footprint of Staffs}

The average ecological footprint of the staffs was calculated as 2.37 gha person ${ }^{-1}$. Akyüz et al (2016) calculated the ecological footprint of the academicians of Ege University Faculty of Agriculture as 3.17 gha person ${ }^{-1}$. Eren et al (2017) calculated the ecological footprint of the academicians of Mustafa Kemal University Faculty of Agriculture as 3.08 gha person ${ }^{-1}$. Eren et al (2018) calculated the ecological footprint of the instructors of İskenderun Technical University as 2.84 gha person ${ }^{-1}$. That is, it can be said that the ecologic footprints of Adiyaman Directorate of Provincial Agriculture and Forestry staffs pollute the world less.

When the staffs were compared ecological footprints according to the titles, the lowest ecological footprint belonged to sociologist with 1.85 gha person $^{-1}$. Sociologist followed the operators with 1.93 gha person ${ }^{-1}$ ecological footprint. The highest ecological footprints were found to belong to officer/employee with 2.45 gha person $^{-1}$ (Figure 6). The ecological footprint varies according to titles, but this difference is not statistically significant $(\mathrm{p}>0.10)$.

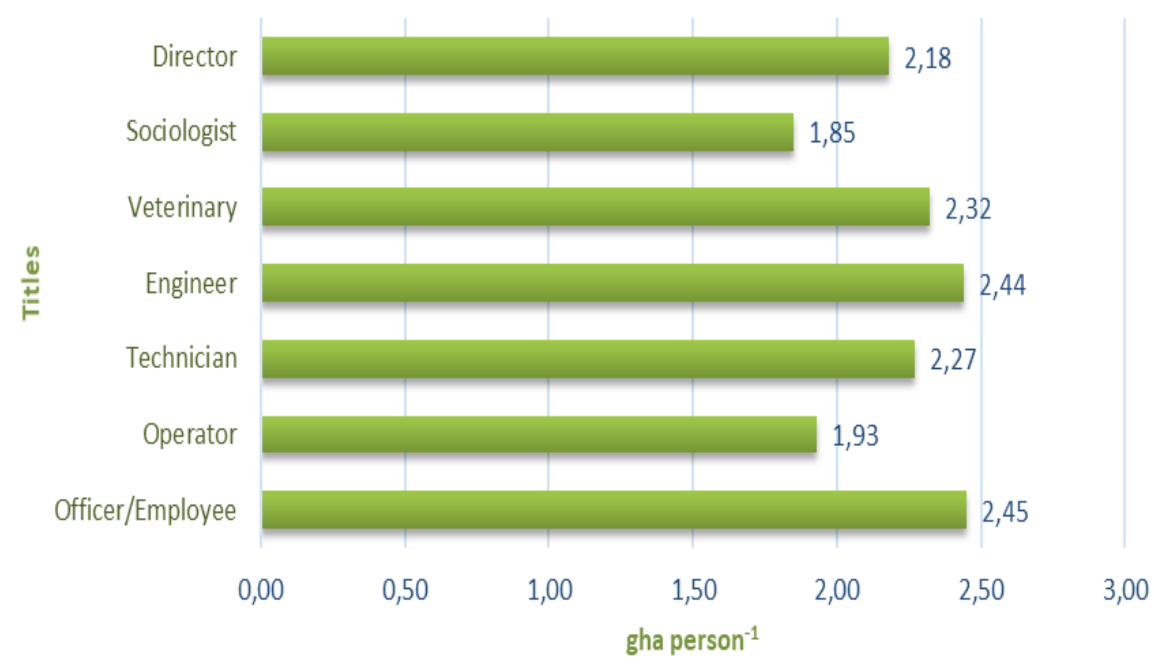

Figure 6. Ecological footprints according to titles of participants 
When the staffs were compared ecological footprints according to the departments the lowest ecological footprint belonged to land consolidation and agricultural infrastructure with 2.06 gha person $^{-1}$. This department followed the fishing and seafood with 2.14 gha person $^{-1}$ ecological footprint. The highest ecological footprints were found to belong to Meadow-Pasture and forage crops with 3.25 gha person ${ }^{-1}$ (Figure 7). The ecological footprint varies according to titles, but this difference is not statistically significant $(p>0.10)$.

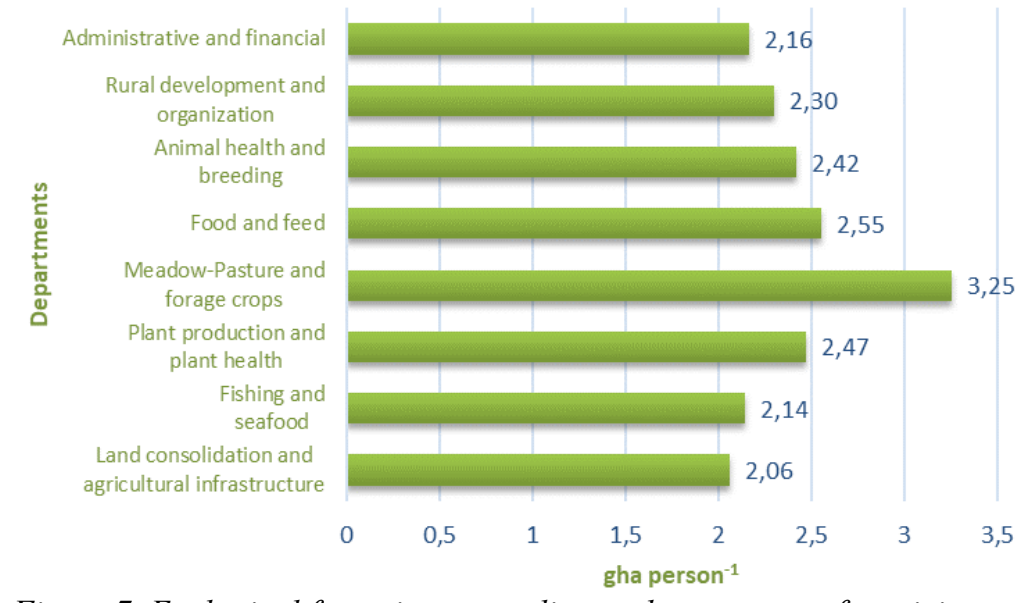

Figure 7. Ecological footprints according to departments of participants

When ecological footprints were analyzed according to the age groups and sex of the staffs, it was determined that the ecological footprints of female participants were higher than male participants. It can be said that the expenditure of jewelry and personal care which are included in the other sources components of the female participants is influential in the formation of this difference. According to age groups, it was determined that the age group of 51 and older age is the most environmentally friendly group in terms of ecological footprint, followed by the group of 35 and less age respectively, and finally the personnel of 36-50 age are in the last place (Figure 8). The ecological footprint of the academicians varied according to age groups and sex but it was determined that this difference was not statistically significant $(\mathrm{p}>0.10)$.

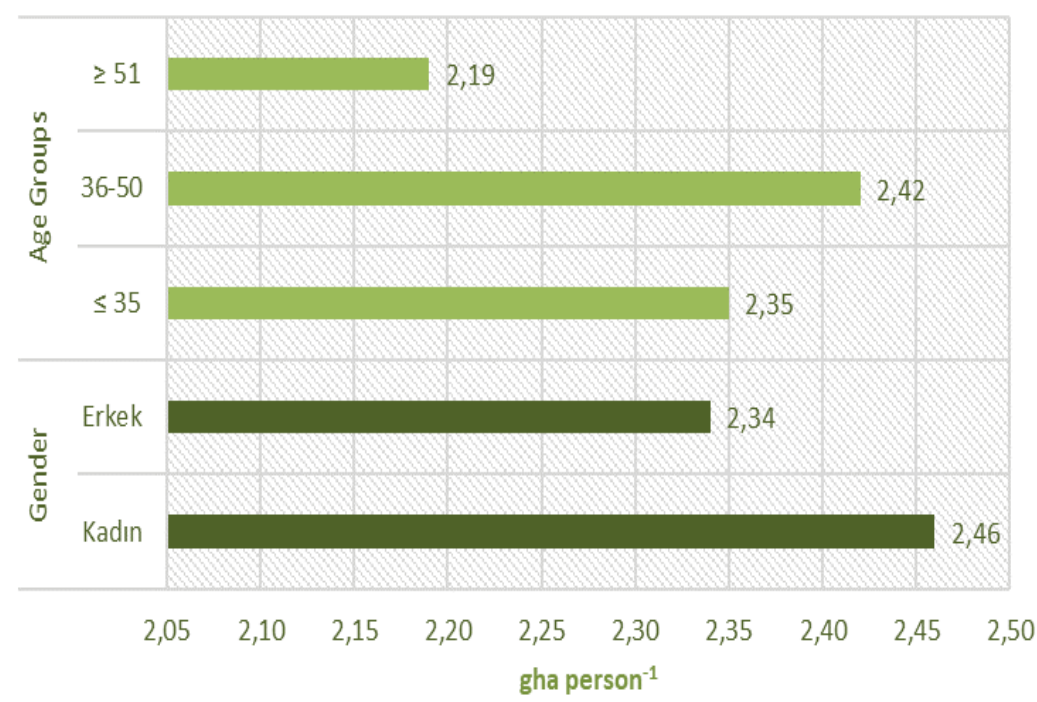

Figure 8. Ecological footprints according to age groups and gender of participants

\subsection{Carbon Footprint of Staffs}

The averages carbon footprint of the staffs was calculated as 14.52 tons person ${ }^{-1}$. Akyüz et al (2016) calculated the carbon footprint of the academicians of Ege University Faculty of Agriculture as 15.32 tons person ${ }^{-1}$. Eren et al (2017) calculated the carbon footprint of the academicians of Mustafa Kemal University Faculty of Agriculture as 14.31 tons person ${ }^{-1}$. Eren et al (2018) calculated the ecological 
footprint of the instructors of İskenderun Technical University as 12.44 tons person ${ }^{-1}$. In other words, the carbon footprint of the Adiyaman Directorate of Provincial Agriculture and Forestry staffs is low according to Akyüz et al (2016) and Eren et al (2017).

The lowest carbon footprint was 11.30 tons person $^{-1}$ for sociologist when evaluated the staffs carbon footprint according to the titles. Sociologist followed the operators with 11.57 tons person $^{-1}$ of carbon footprint. It was determined that the highest carbon footprint belongs to officer/employee with 15.00 tons person $^{-1}$ (Figure 9). The carbon footprint of instructors varies according to the titles, but this difference is not statistically significant $(\mathrm{p}>0.10)$.

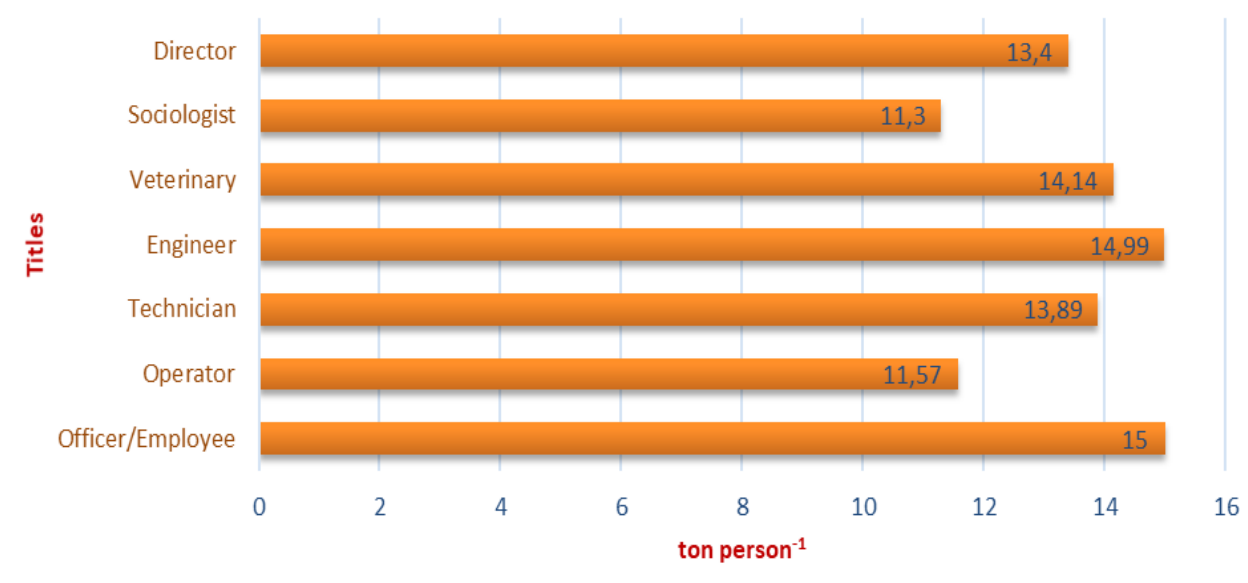

Figure 9. Carbon footprints according to titles of participants

When the staffs were compared carbon footprints according to the departments the lowest carbon footprint belonged to land consolidation and agricultural infrastructure with 12.53 ton person ${ }^{-1}$. This department followed the fishing and seafood with 13.22 ton person $^{-1}$ carbon footprint. The highest carbon footprints were found to belong to Meadow-Pasture and forage crops with 20.35 gha person $^{-1}$ (Figure 10). The ecological footprint varies according to titles, but this difference is not statistically significant ( $\mathrm{p}>0.10$ ).

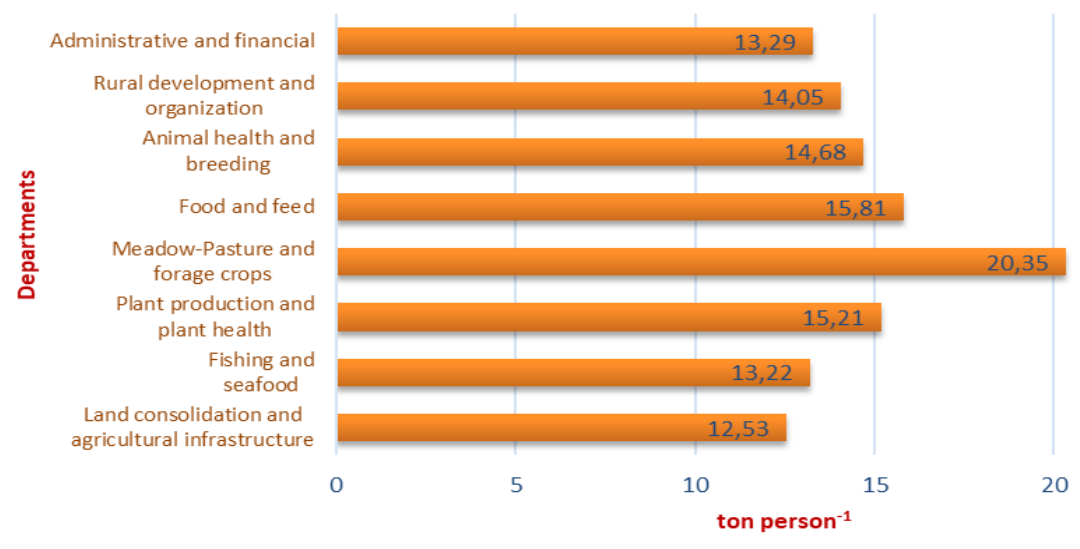

Figure 10. Carbon footprints according to departments of participants

When carbon footprint analysis was conducted according to the age groups and sex of the instructors, the carbon footprint of female participants was found to be higher than male participants. According to age groups, it was determined that the age group of 51 and older age is the most environmentally friendly group in terms of ecological footprint, followed by the group of 35 and less age respectively, and finally the personnel of 36-50 age are in the last place (Figure 11). The carbon footprint varies according to age groups and sex but this difference is not statistically significant $(\mathrm{p}>0.10)$. 


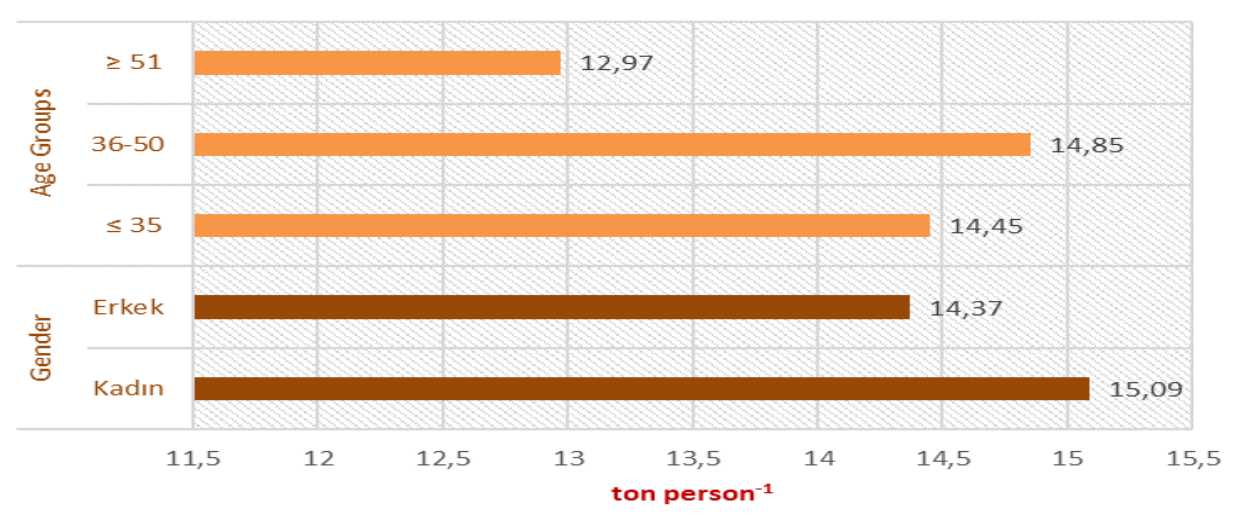

Figure 11. Carbon footprints according to age groups and gender of participants

\subsection{Biocapacity Defict and Number of Earths}

Biocapacity deficit caused by staffs calculated as -0.93 gha person $^{-1}$ according to Turkey's biocapacity value (1.44 gha person $\left.{ }^{-1}\right)$. Lastly, the staffs of Adiyaman Directorate of Provincial Agriculture and Forestry need 1.4 Earths for a sustainable life (Figure 12).

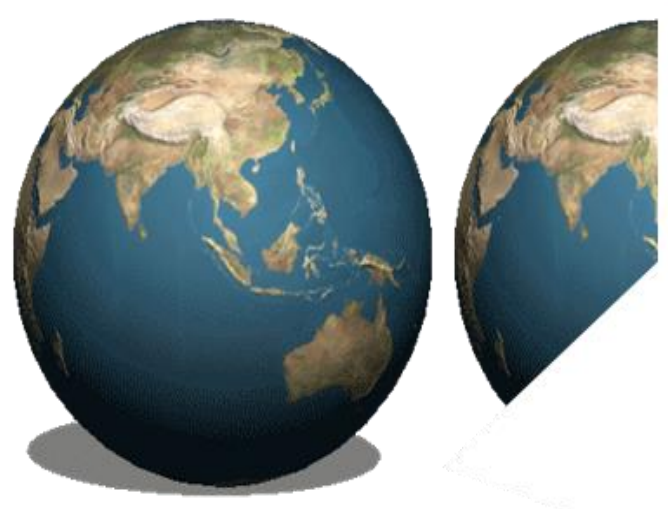

Figure 12. Number of earths

\section{Conclusion}

In this study, the ecological and carbon footprints of the surveyed staffs were calculated with face to face interviews with 143 participants from Adiyaman Directorate of Provincial Agriculture and Forestry. According to the results obtained; the ecological footprint of the staffs is below the average of 2.84 gha person ${ }^{-1}$ in the world average and 3.21 gha person ${ }^{-1}$ in Turkey.

It can be said that the sociologist are more environmentally friendly than the staffs with other titles because of their low ecological and carbon footprints and need an average of 1.3 worlds for a sustainable life.

Suggestions can be made to change the life habits of Adıyaman Directorate of Provincial Agriculture and Forestry faculty members in order to draw even lower ecological and carbon footprints, leave a more environmentally friendly nature for future generations, and prevent the depletion of biological diversity. These;

- Wherever possible, the use of public transport should be encouraged, measures must be taken to save energy in homes and offices, and household waste should be separated to enable recycling.

- Natural resources should be used in ways that do not exceed ecological boundaries and should increase protected areas.

- Environment friendly, recyclable and reusable products should be preferred rather than the production, distribution, transfer and use of synthetic, chemical, toxic substances, heavy metals, polluting gases that nature cannot convert.

- Excessive water waste should be avoided.

- Meat and meat products should be consumed without overdoing and local products should be preferred especially for food consumption.

\section{Acknowledgement}


This paper was submitted as oral abstract in International Congress on Agriculture and Animal Sciences (7-9 November 2018, Alanya-Turkey).

\section{References}

Akıllı H, Kemahlı F, Okudan K, Polat F, 2008. Ekolojik ayak izinin kavramsal içeriği ve Akdeniz Üniversitesi İktisadi ve İdari Bilimler Fakültesi'nde bireysel ekolojik ayak izi hesaplaması. Akdeniz I.I. B.F. Dergisi, 15: 1-25. (Turkish)

Akyüz Y, Atış E, Çukadar M, Salalı E, 2016. Akademisyenlerin ekolojik etkilerinin incelenmesi: E.Ü. Ziraat Fakültesi örneği. XII. Ulusal Tarım Ekonomisi Kongresi Bildiriler Kitab1, 1427-1436, 25-27 Mayıs 2016, Isparta. (Turkish)

Coşkun IÇ, 2013. Sınıf öğretmeni adaylarının ekolojik ayak izi farkındalık düzeylerinin belirlenmesi. Gazi Üniversitesi Eğitim Bilimleri Enstitüsü İlköğretim Ana Bilim Dalı Sınıf Öğretmenliği Bilim Dalı Yüksek Lisans Tezi, Ankara. (Turkish)

Çetin FA, 2015. Ekolojik ayak izi eğitiminin 8. sınıf öğrencilerinin sürdürülebilir yaşama yönelik tutum, farkındalık ve davranış düzeyine etkisi. Gazi Üniversitesi Eğitim Bilimleri Enstitüsü İlköğretim Ana Bilim Dalı Fen Bilgisi Öğretmenliği Bilim Dalı Yüksek Lisans Tezi, Ankara. (Turkish)

Dawe FMG, Vetter A, Martin S, 2004. An overview of ecological footprinting and other tools and their application to the development of sustainability process: Audit and methodology at Holme Lacy College, UK. International Journal of Sustainability in Higher Education, 5 (4): 340-371.

Dinç A, 2015. Bir sürdürülebilir kalkınma göstergesi olarak ekolojik ayak izi ve Türkiye. Anadolu Üniversitesi Sosyal Bilimler Enstitüsü Yüksek Lisans Tezi, Eskişehir. (Turkish)

Eren B, Aygün A, Chabanow D, Akman N, 2016. Mühendislik öğrencileri ekolojik ayak izinin belirlenmesi. 3rd International Symposium on Environment and Morality (ISEM2016), 4-6 November 2016, Alanya-Turkey. (Turkish)

Eren Ö, Parlakay O, Hilal M, Bozhüyük B, 2017. Ziraat Fakültesi akademisyenlerinin ekolojik ayak izinin belirlenmesi: Mustafa Kemal Üniversitesi örneği. Gaziosmanpaşa Üniversitesi Ziraat Fakültesi Dergisi, 34 (2): 138-145. (Turkish)

Eren Ö, Uğurluay S, Söyler O, Çakır M, Kalpakçıŏlu H, 2018. Determination of Ecological Footprint of Instructors and Biocapacity Deficit in Turkey: A Case Study of Hatay-Iskenderun Region. International Journal of Scientific and Technological Research, 4 (4), 90-96.

Erdoğan M, Tuncer G, 2009. Evaluation of a course: "Education and awareness for sustainability". International Journal of Environmental \& Science Education, 4(2): 133-146

GFN, 2019. Global footprint network. Online available: http://data.footprintnetwork.org/\#/ (January 15, 2019)

Janis AJ, 2007. Quantifying the ecological footprint of the Ohio State University. Ph.D Thesis. The Ohio State University, Columbus

Keleş Ö, 2007. Sürdürülebilir yaşama yönelik çevre eğitimi aracı olarak ekolojik ayak izinin uygulanması ve değerlendirilmesi. Gazi Üniversitesi Eğitim Bilimleri Enstitüsü İlköğretim Ana Bilim Dalı Sınıf Öğretmenliği Bilim Dalı Doktora Tezi, Ankara. (Turkish)

Keleş Ö, 2011. Öğrenme halkası modelinin öğrencilerin ekolojik ayak izlerini azaltmasına etkisi. Gazi Üniversitesi Sosyal Bilimler Dergisi, 10(3): 1143-1160. (Turkish)

Keleş Ö, Uzun N, Özsoy S, 2008. Öğretmen adaylarının ekolojik ayak izlerinin hesaplanması ve değerlendirilmesi. Ege Eğitim Dergisi, 9(2): 1-14. (Turkish)

Lin D, Hanscom L, Martindill J, Borucke M, Cohen L, Galli A, Lazarus E, Zokai G, Iha K, Eaton D, Wackernagel M, 2016. Working Guidebook to the National Footprint Accounts: 2016 Edition. Oakland.

Niccolucci, V., Tiezzi, E., Pulselli, F.M., Capineri, C., 2012. Biocapacity vs Ecological Footprint of world regions: A geopolitical interpretation. Ecological Indicators, 16: 23-30.

Ryu CH, Brody SD, 2006. Can higher education influence sustainable behavior? Examining the impacts of a graduate course on sustainable development Using ecological footprint analysis. International Journal of Sustainability in Higher Education, 7(2): $158-175$.

Schaller D, 1999. Our footprints-they're all over the place. Newsletter of the Utah Society for Enviromental Education, 9 (4).

Wada Y, Izumi K, Mashiba T, 2007. Development of a web-based personal ecological footprint calculator for the Japanese. International Ecological Footprint Conference, 8-10 May. Cardiff.

WWF, 2018. Footprint calculator. Online available: http://footprint.wwf.org.uk/questionnaires/show/1/1/1, Adresinden Alınd1, (May 15,2018 